\title{
Growth models for morphological traits of sunn hemp
}

\section{Modelos de crescimento em caracteres morfológicos de crotalária juncea}

\author{
Cláudia Marques de Bem ${ }^{1}$; Alberto Cargnelutti Filho ${ }^{2 *}$; Giovani Facco3; \\ Denison Esequiel Schabarum ${ }^{4}$; Daniela Lixinski Silveira ${ }^{5}$; \\ Fernanda Martins Simões ${ }^{5}$; Daniela Barbieri Uliana ${ }^{6}$
}

\begin{abstract}
The objective of the present study was to fit Gompertz and Logistic nonlinear to descriptions of morphological traits of sunn hemp. Two uniformity trials were conducted and the crops received identical treatment in all experimental area. Sunn hemp seeds were sown in rows $0.5 \mathrm{~m}$ apart with a plant density of 20 plants per row meter in a usable area of $52 \mathrm{~m} \times 50 \mathrm{~m}$. The following morphological traits were evaluated: plant height (PH), number of leaves (NL), stem diameter (SD), and root length (RL). These traits were assessed daily during two sowing periods - seeds were sown on October 22, 2014 (first period) and December 3, 2014 (second period). Four plants were randomly collected daily, beginning 7 days after first period and 13 days after for second period, totaling 94 and 76 evaluation days, respectively. For Gompertz models the equation was used $y=a * e^{\left(-e^{(b-c * x i))}\right.}$ and Logistic models the equation was used $y i=\frac{a}{1+e^{(-b-c * x i)}}$. The inflection points of the Gompertz and Logistic models were calculated and the goodness of fit was quantified using the adjusted coefficient of determination, Akaike information criterion, standard deviation of residuals, mean absolute deviation, mean absolute percentage error, and mean prediction error. Differences were observed between the Gompertz and Logistic models and between the experimental periods in the parameter estimate for all morphological traits measured. Satisfactory growth curve fittings were achieved for plant height, number of leaves, and stem diameter in both models using the evaluation criteria: coefficient of determination $\left(R^{2}\right)$, Akaike information criterion (AIC), standard deviation of residuals (SDR), mean absolute deviation (MAD), mean absolute percentage error (MAPE), and mean prediction error (MPE).
\end{abstract}

Key words: Cover crop. Experimental planning. Modeling.

\section{Resumo}

O objetivo deste trabalho foi ajustar modelos não lineares, Gompertz e Logístico, na descrição dos caracteres morfológicos de crotalária juncea. Foram realizados dois ensaios de uniformidade e os tratos culturais foram os mesmos em toda área experimental. A semeadura foi realizada em fileiras espaçadas de $0,5 \mathrm{~m}$, com a densidade de 20 plantas por metro de fileira em área útil de $52 \mathrm{~m} \times 50 \mathrm{~m}$.

\footnotetext{
1 Zootecnista, Discente de Doutorado, Programa de Pós-Graduação em Agronomia, Universidade Federal de Santa Maria, UFSM, Santa Maria, RS, Brasil. E-mail: claudia_debem@hotmail.com

${ }^{2}$ Eng $^{\circ}$ Agr $^{\circ}$, Prof. Dr., Departamento de Fitotecnia, UFSM, Santa Maria, RS, Brasil. E-mail: alberto.cargnelutti.filho@gmail.com

${ }^{3}$ Eng $^{\circ}$ Agr $^{\circ}$, Dr, Programa de Pós-Graduação em Agronomia, UFSM, Santa Maria, RS, Brasil. E-mail: giovanifacco2011@gmail.com

${ }^{4}$ Eng $^{\circ}$ Agr $^{\circ}$, M.e, Programa de Pós-Graduação em Agronomia, UFSM, Santa Maria, RS, Brasil. E-mail: denisonesequiel@yahoo. com.br

${ }^{5}$ Discentes de Graduação em Agronomia, UFSM, Santa Maria, RS, Brasil. E-mail: danilisil@gmail.com; fernandadompedrito@ gmail.com

${ }^{6}$ Eng $^{\mathrm{a}}$ Agra , Discente de Mestrado, Programa de Pós-Graduação em Agrobiologia, UFSM, Santa Maria, RS, Brasil. E-mail: danibarbieriuliana@hotmail.com

* Author for correspondence
} 
Foram avaliados os caracteres morfológicos: altura de planta, número de folhas, diâmetro de caule e comprimento de raiz. Estas variáveis foram avaliadas, diariamente, em duas épocas de semeadura, 22 de outubro de 2014 (época 1) e 03 de dezembro de 2014 (época 2), totalizando 94 e 76 dias de avaliação, respectivamente. Para a época 1, aos 7 dias após a semeadura, e para a época 2, aos 13 dias após a semeadura, foram coletadas, aleatoriamente, quatro plantas em cada dia. Para o modelo de Gompertz foi

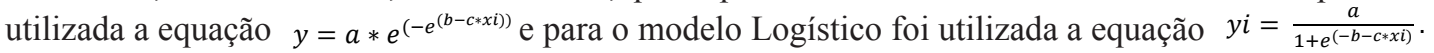
Foi calculado o ponto de inflexão para os modelos Gompertz e Logístico. A qualidade do ajuste dos modelos Gompertz e Logístico foi verificada pelo coeficiente de determinação ajustado, critério de informação de Akaike, desvio padrão residual, desvio médio absoluto, erro percentual médio absoluto e erro de predição médio. Os modelos de Gompertz e Logístico diferem entre si e entre as épocas de semeadura, para as estimativas dos parâmetros para altura de planta, número de folhas, diâmetro de caule e comprimento de raiz. As curvas de crescimento, para os caracteres altura de planta, número de folhas e diâmetro de caule, apresentaram ajustes satisfatórios para ambos os modelos, utilizando os seguintes critérios de avaliação: coeficiente de determinação ajustado, critério de informação de Akaike, desvio padrão residual, desvio médio absoluto, erro percentual médio absoluto e erro de predição médio.

Palavras-chave: Modelagem. Planejamento experimental. Planta de cobertura.

\section{Introduction}

The sunn hemp (Crotalaria juncea L.) is a fastgrowing legume species, especially under hightemperature conditions. It is an excellent crop for green manure because of its growth characteristics and adaptation to local edaphoclimatic conditions (LEAL et al., 2012). It is known for having high rates of biomass production and nutrient turnover, easy decomposition and efficient biological fixation of atmospheric nitrogen (DOURADO et al., 2001), and the ability to reduce risk of erosion as well as damage caused by nematodes and weeds (DINARDO-MIRANDA; GIL, 2005).

The planting of legumes is common among farmers who cultivate green manure crops; this agroecological practice does not require conventional fertilization (with chemical products) and instead uses the biomass of the legumes to assist with biological fixation of nitrogen in the soil. In the micro-basin Campo de Areia, in São João da Barra, in the North Fluminense (Rio de Janeiro State) region, the planting of sunn hemp, one of the most common legume crops, has been promoted by the Rio Rural Program of the State Secretariat of Agriculture. Because of the extensive use of this crop, modeling the processes involved in its growth up to the completion of its production cycle has become an important management tool.
One method for characterizing the growth of a certain crop is via modeling (STRECK et al., 2008), whereby prediction models are applied both before seed sowing and during crop growth. Fitting growth models to plant species facilitates the evaluation of species response to environmental conditions and provides an understanding of growth patterns (LYRA et al., 2003); thus, growth models are an important scientific tool.

Mathematical models should reproduce the original behavior of the system in the most accurate way. Haefner (2005) defined mathematical modeling as the determination of a set of mathematical equations (models) that describe a system. Modeling aims to minimize production costs, reduce potential losses associated with environmental risks, and provide greater planning sustainability. Nonlinear regression models are useful for describing growth curves; they contribute to and facilitate the interpretation of the processes involved in plant growth because their parameters allow practical interpretation (SORATO et al., 2014). However, the use of these models depends on the research field, the problem that needs to be solved, and the type of growth that needs to be modeled (DRAPER; SMITH, 1981).

Nonlinear model fitting is frequently utilized in a variety of research areas. In plant production, it 
has been applied in the study of cryopreservation of aroeira (Astronium urundeuva Engl) and baraúna (Schinopsis brasiliensis Engl) seeds (GONZAGA et al., 2003) utilized the Gompertz and Logistic models, the study of the dynamics and availability of nutrients in the soil/plant system (PEREIRA et al., 2005) utilized the Gompertz and Logistic models, and the study of plant species growth (MARTINS FILHO et al., 2008) utilized the Logistic model. Terra et al. (2010) reported that these models offer the possibility of condensing information from a series of data collected over time into a smaller set of biologically interpretable parameters.

Among nonlinear models, the Gompertz and Logistic models have been utilized to describe various biological processes via growth curves produced by the equations corresponding to each model. These models generate sigmoidal curves whereby growth curves expand slowly in the beginning of the development, have an inflection point, and reach a maximum in the upper asymptote. To our know ledge, no detailed studies have been conducted describing the development of sunn hemp using statistical models.

Therefore, the objective of the present study was to investigate the fitting of Gompertz and Logistic nonlinear models to the description of morphological traits of sunn hemp (Crotalaria juncea L.): plant height, number of leaves, stem diameter, and root length, during two experimental periods.

\section{Material and Methods}

Two uniformity trials (experiments without treatments) were conducted with sunn hemp (Crotalaria juncea L.) during the 2014/2015 harvest, in an experimental area of the Department of Plant Science at the Federal University of Santa Maria, Rio Grande do Sul State. The sunn hemp seeds were sown on two periods, the first sowing period on October 22, 2014 and the second period on December 3, 2014. On both periods, was performed in rows $0.5 \mathrm{~m}$ apart with a density of 20 plants per row meter in a usable area of $52 \mathrm{~m} \times 50 \mathrm{~m}$. The fertilization consisted of $15 \mathrm{~kg} \mathrm{ha}^{-1}$ of $\mathrm{N}, 60 \mathrm{~kg} \mathrm{ha}^{-1}$ of $\mathrm{P}_{2} \mathrm{O}_{5}$, and $60 \mathrm{~kg} \mathrm{ha}^{-1}$ of $\mathrm{K}_{2} \mathrm{O}$. Evaluations of sunn hemp commenced on October 29, 2014 for first period and December 16, 2014 for second period, and totaled 94 and 76 evaluation days, respectively.

After the emergence of sunn hemp seeds, four plants were randomly collected daily, beginning 7 days after first period and 13 days after for second period. The following morphological traits were evaluated: plant height $(\mathrm{PH})$, number of leaves (NL), stem diameter (SD), and root length (RL). A millimeter ruler was used to measure $\mathrm{PH}$ and $\mathrm{RL}$ in $\mathrm{cm}$, NL was obtained by counting the number of green leaves, and SD was measured in mm using a pachymeter. For these morphological traits, the Gompertz and Logistic models were fitted as a function of days after sowing (DAS).

The Gompertz model was given by the equation $y i=a * e^{\left(-e^{(b-c * x i))}\right.}$ where $y i$ is the it observation of the dependent variable, with $\mathrm{i}=1,2, \ldots, \mathrm{n}$ and $\mathrm{n}$ is number the observation; $x i$ is the ith observation of the independent variable; $a$ is the asymptotic value; $b$ is a location parameter without direct practical interpretation but with importance for maintaining the sigmoidal shape of the model; $c$ is associated with growth and indicates the rate of maturity or precociousness. The higher the value of $c$, the less time is required for the plant to reach the asymptotic value $(a)$; and $\varepsilon i$ is the vector of errors associated with the models. In addition, the inflection point (IP) was calculated by $x i=\frac{b}{c}$ and $y i=\frac{a}{e}$, where $a, b$, and $c$ are model parameters, and $e$ is the base of the neperiano logarithm. The Logistic model was given by the equation: $y i=\frac{a}{1+e^{(-b-c * x i)}}$, in addition, the inflection point (IP) was calculed by $x i=\frac{-b}{c}$ and $y i=\frac{a}{2}$. All parameter are the same as those defined above. For the estimation the parameters of the Gompertz and Logistic models, we used the Method of Least Square. The calculations were performed with the help of SOLVER of Microsoft Office Excel ${ }^{\circledR}$ application and software statistic R (R DEVELOPMENT CORE TEAM, 2017). 
The following parameters were utilized to evaluate the goodness of fit of the Gompertz and Logistic models: coefficient of determination: $R^{2}=S Q R / S Q T$, were $S Q R$ is the sum of residue square, $S Q T$ is the sum of total square, the best model had the highest $R^{2}$ value; Akaike information criterion: $A I C=\ln \left(\sigma^{2}\right)+2(p+1) / n$, were $\ln \left(\sigma^{2}\right)$ is the logarithm of the variance model, $p$ is the number of model parameters, and $\mathrm{n}$ is the sample size, and $n$ is number of parameters model, the best model had the lowest value; standard deviation of the residuals: $S D R=\sqrt{M S E}$, were $M S E$ is the mean square error, the lower the QMR value, the better the fit of the model; mean absolute deviation: $M A D$ $=\frac{\sum_{i=1}^{n}|y i-\widehat{y} \mathrm{l}|}{n}$, the lower the value, the better the fit of the model; mean absolute percentage error: $M A P E=\frac{\sum_{i=1}^{n}\left|\frac{y i-\widehat{y u}}{y i}\right|}{100}$, the best fitting model had the lowest value; and mean prediction error: $M P E$ $=\frac{1}{n} \sum_{i=1}^{n} E P i$, measures the adherence of the estimated data to the obtained data (MAIA et al., 2009). The calculations were performed with the help of Microsoft Office Excel ${ }^{\circledR}$ application and software statistic R (R DEVELOPMENT CORE TEAM, 2017).

\section{Results and Discussion}

Data on the morphological traits collected daily for each sunn hemp plant during the two experimental periods, were utilized to fit the Gompertz and Logistic models. For all the assessed traits, there was convergence in both models. Displays the results of the criteria for the evaluation of goodness of fit, based on the assessed models, obtained for plant height $(\mathrm{PH})$, number of leaves $(\mathrm{NL})$, stem diameter (SD), and root length (RL) (Table 1).

Table 1. Criteria for evaluation the quality fit: coefficient of determination $\left(R^{2}\right)$, Akaike information criterion (AIC), standard deviation of residuals (SDR), mean absolute deviation (MAD), mean absolute percentage error (MAPE), and mean prediction error (MPE) for Gompertz and Logistic models, for plant height (in cm), number of leaves, stem diameter (in $\mathrm{mm}$ ), and root length (in $\mathrm{cm}$ ), using days after sowing during two sowing periods. Santa Maria, RS, 2014.

\begin{tabular}{lccccccc}
\hline Traits & Model & $R^{2}$ & AIC & SDR & DMA & MAPE & MPE \\
\hline Plant height & \multicolumn{7}{c}{ First sowing period (October 22, 2014) } \\
& Gompertz & 0.91 & 6.46 & 47.70 & 0.0112 & 0.0109 & 1.0857 \\
& Logístico & 0.91 & 6.50 & 48.63 & 0.0050 & 0.0048 & -0.4748 \\
Number of leaves & Gompertz & 0.85 & 5.28 & 26.44 & 0.0014 & 0.0029 & 0.2861 \\
& Logístico & 0.85 & 5.31 & 26.81 & 0.0030 & 0.0063 & -0.6320 \\
Stem diameter & Gompertz & 0.85 & 1.27 & 3.56 & 0.0009 & 0.0141 & 1.4084 \\
& Logístico & 0.85 & 1.24 & 3.52 & 0.0049 & 0.0003 & 0.4857 \\
Root length & Gompertz & 0.49 & 2.61 & 6.98 & 0.0005 & 0.0044 & 0.4390 \\
& Logístico & 0.51 & 2.58 & 6.86 & 0.0006 & 0.0061 & 0.6080 \\
\hline \multirow{7}{*}{ Plant height } & Second sowing period (December 3,2014) & & \\
Number of leaves & Gompertz & 0.88 & 6.75 & 52.66 & 0.0093 & 0.0086 & 0.7525 \\
& Logístico & 0.88 & 6.74 & 52.47 & 0.0030 & 0.0027 & -0.2418 \\
Stem diameter & Gompertz & 0.71 & 5.64 & 30.25 & 0.0059 & 0.0140 & 1.2301 \\
& Logístico & 0.72 & 5.60 & 29.70 & 0.0023 & 0.0054 & 0.4732 \\
Root length & Gompertz & 0.72 & 1.19 & 3.28 & 0.0002 & 0.0038 & 0.3305 \\
& Logístico & 0.72 & 1.18 & 3.27 & 0.0000 & 0.0006 & 0.0550 \\
& Gompertz & 0.54 & 2.10 & 5.16 & 0.0000 & 0.0004 & 0.0329 \\
& Logístico & 0.54 & 2.10 & 5.17 & 0.0001 & 0.0008 & -0.0677 \\
\hline
\end{tabular}

*First sowing periods = October 22, 2014 and evaluation $=$ October 29, $2014(x i=7)$; Second sowing periods $=$ December 3, 2014 and evaluation $=$ December $16,2014(x i=13)$. 
It is observed in Table 1 shows that the values of the coefficient of determination were higher than 0.80 in both models during first period for $\mathrm{PH}, \mathrm{NL}$, and SD, which indicates that, in general, the data of these traits fitted well with the models that converged. However, this result was not observed for RL that had values of 0.49 and 0.51 for the Gompertz and Logistic models, respectively. Similar results were obtained during second period; however, the values of the coefficient of determination were lower than those that were obtained during first period. Therefore, there was no difference between the Gompertz and Logistic models with regard to the goodness of fit criterion during both periods. In addition, $R^{2}$ measured the total percentage of the variation of these traits and the models had different variation values, with the residual of this variation being attributed to other factors that were not included in the model, such as environmental factors.

Several authors have utilized the coefficient of determination as the criterion for evaluating the goodness of fit in models. Deprá et al. (2016) studied the logistic model for creole corn cultivar growth and obtained values of $R^{2}$ greater than 0.85 , while Fernandes et al. (2014) conducted a study comparing nonlinear regression models in coffee and concluded that the Gompertz model provided the best fit $\left(R^{2}\right)$. Lyra et al. (2013) evaluated growth curves of papaya crops using Gompertz and Logistic models for the variables $\mathrm{PH}, \mathrm{SD}$, and canopy diameter, and obtained values of $R^{2}$ greater than 0.86 , which allowed utilization of the models to fit growth curves to these variables. These results demonstrate that $R^{2}$ is important and useful as a tool to compare the growth models because of its high explanatory power.

In addition to $R^{2}$, the remaining criteria to assess the goodness of fit for the models being studied were of great importance for evaluating the morphological traits of sunn hemp. The comparison between the results of AIC and SDR of the fitted models during each experimental period showed the following, during first period, the Gompertz model was the best-fitting model for the PH and NL traits, although the difference between the models was small, however, the Logistic model was the best-fitting model for the SD and RL traits because it yielded the lowest values of the two evaluation criteria. For during second period, there was also a small difference between the models with regard to PH, NL, SD, and RL; however, the Logistic model yielded the lowest AIC and SDR values. Moreover, the values obtained for the MAD and MAPE criteria were virtually identical in both models during each experimental period; and lower values indicated a good fit for both models to the data obtained for $\mathrm{PH}$, $\mathrm{NL}, \mathrm{SD}$, and RL during first and second periods. However, the values of the MPE criterion differed between the models and experimental periods, with positive values indicating that the function underestimated the observed values and negative values indicating that the function overestimated the observed values.

Several studies have focused on the use of these evaluation criteria, namely Dionello et al. (2009) who studied models describing pineapple drying curves using $R^{2}$, SDR, and MAPE as selection criteria; Terra et al. (2010) who applied $R^{2}$, SDR, and AIC as evaluation criteria to analyze the fitting of Gompertz and Logistic models to data of pygmy date palm fruits; Reis et al. (2014) who studied clusters of garlic accessions, and concluded that, based on $R^{2}$, MSE, and MAD, the best-fitting model was the Logistic model; Lúcio et al. (2015) who analyzed nonlinear models in the production of pumpkin and bell pepper using $R^{2} a j$ and standard error as evaluation criteria; and Deprá et al. (2016) who evaluated logistic models for the growth of creole corn cultivars and of maternal half-sib progeny using $R^{2}$ and MAD to assess goodness of fit. Silveira et al. (2012) reported that the greater the number of evaluation criteria applied, the more adequate is the indication of which are the bestfitting models. Therefore, the researcher must decide the best criteria to utilize that will best explain the research results. 
Displays the parameter estimates of the Gompertz and Logistic models (Table 2). These functions have two biologically interpretable parameter and a third one considered the mathematical constant. These parameters were applied to the equations of the two models in the present study. Regarding the PH traits during first period, the Gompertz model indicated an asymptotic weight of $262.70 \mathrm{~cm}$ and the Logistic model exhibited an $a$ of $232.87 \mathrm{~cm}$; these values are representative of the asymptotic weight for $\mathrm{PH}$. Regarding the NL, SD, and RL traits, this parameter also yielded satisfactory values, although there was a difference between the fitted models with the values being higher in the Gompertz model than in the Logistic model. During second period, the results were also higher in the Gompertz model; however, both models provided good representation of the asymptotic weight for the PH, NL, SD, and RL traits.
The interpretation of this parameter is extremely important because it provides information regarding the maximum value that each measured traits will attain at the end of the plant's life cycle, thereby leading to increased knowledge on the growth of the crop. The estimates of parameter $b$ differed between experimental periods and growth models. However, because this parameter does not have a biological interpretation and is only a location parameter, these results did not indicate a fitting problem. In a study on the germination of coffee seeds, Sousa et al. (2014) concluded that the parameters of the Gompertz and Logistic models exhibited adequate biological interpretation, fitting to the traits of each models parameter. Similar results were observed in the present study, whereby the values obtained for the models parameter fitted with the assessed traits.

Table 2. Parameter estimates and standard error (SE) for the Gompertz and Logistic models, for plant height (in $\mathrm{cm}$ ), number of leaves, stem diameter (in $\mathrm{mm}$ ), and root length (in $\mathrm{cm}$ ), using days after sowing (DAS) during two sowing periods. Santa Maria, RS, 2014.

\begin{tabular}{llcccccc}
\hline Traits & Models & $a$ & SE & $b$ & SE & $c$ & SE \\
\hline Plant height & & \multicolumn{7}{c}{ First sowing period (October 22, 2014) } \\
& Gompertz & 262.70 & 9.95 & 2.30 & 0.1217 & 0.0431 & 0.0029 \\
Number of leaves & Logístico & 232.87 & 5.42 & -4.49 & 0.1891 & 0.0764 & 0.0039 \\
& Gompertz & 121.98 & 7.25 & 1.76 & 0.1016 & 0.0339 & 0.0031 \\
& Logístico & 102.78 & 3.40 & -3.66 & 0.1805 & 0.0646 & 0.0042 \\
Stem diameter & Gompertz & 14.66 & 0.64 & 1.84 & 0.1152 & 0.0397 & 0.0033 \\
& Logístico & 13.01 & 0.33 & -3.74 & 0.1927 & 0.0715 & 0.0045 \\
Root length & Gompertz & 14.12 & 0.40 & 1.17 & 0.1650 & 0.0590 & 0.0073 \\
& Logístico & 13.92 & 0.32 & -2.36 & 0.2653 & 0.0859 & 0.0097 \\
\hline \multirow{7}{*}{ Plant height } & & & Second sowing period (December 3,2014) & \\
& Gompertz & 304.10 & 28.21 & 2.06 & 0.1089 & 0.0391 & 0.0035 \\
Number of leaves & Logístico & 257.65 & 10.35 & -4.26 & 0.1990 & 0.0746 & 0.0048 \\
Stem diameter & Gompertz & 85.23 & 5.10 & 2.25 & 0.2399 & 0.0533 & 0.0069 \\
& Logístico & 78.31 & 2.92 & -4.46 & 0.3837 & 0.0930 & 0.0093 \\
Root length & Gompertz & 10.92 & 0.76 & 1.61 & 0.1429 & 0.0405 & 0.0051 \\
& Logístico & 9.63 & 0.39 & -3.28 & 0.2462 & 0.0725 & 0.0070 \\
& Gompertz & 23.70 & 8.01 & 0.78 & 0.2027 & 0.0165 & 0.0056 \\
& Logístico & 23.70 & 7.96 & -1.80 & 0.2765 & 0.0257 & 0.0061 \\
\hline
\end{tabular}

${ }^{*}$ First sowing periods $=$ October 22, 2014 and evaluation $=$ October 29, $2014(x i=7)$; Second sowing periods $=$ December 3,2014 and evaluation $=$ December $16,2014(x i=13)$. 
Based on the study of nonlinear regression models by Draper and Smith (1998), the system of normal equations is not a closed one to estimate the parameter, rather these estimates are obtained via iterative methods. This process consists of starting from the initial values of the parameter and improving them until convergence to the real value is achieved. Therefore, the choice of the initial value is the most important step in the process and is performed using computational methods or the analysis of data and experience of the researcher (FERNANDES et al., 2014). Thus, the data collected should be analyzed carefully so that they are close to real experimental values, which allows for a better fit and greater reliability of the models fitted to the traits under study to be obtained.

It should be noted that the parameter of the Gompertz and Logistic models, with DAS as the independent variable, were adjusted to the local conditions and experimental periods (sowing first period and sowing second period). Therefore, if the parameters obtained in the present study are utilized to estimate the growth of sunn hemp in other regions, the estimated values (using DAS as the independent variable) might diverge from those obtained in the present study, which is to be expected because of the differences that exist between regions and sowing periods. However, the present study serves as a reference for future research because to our knowledge there are currently no studies that utilize the modeling method to evaluate morphological traits of sunn hemp crops.

Displays the growth curves (Figure 1), their respective equations, and IP (xi, yi) for the Gompertz and Logistic models during first period with regard to the PH, NL, SD, and RL traits. This figure illustrates that the curves provide a satisfactory representation of the models fitted to these traits. The equation of the Gompertz model fitted to $\mathrm{PH}$ in first period was $y i=262.70 * e^{\left(-e^{(2.30-0.0431 * x i))}\right.}$ and that of the Logistic model was $y i=\frac{232.87}{1+e^{(4.49-0.0764 * x i)}}$ using DAS as the independent variable. Therefore, replacing the value of $x i$ by days would yield the maximum height of the plant during a certain period of its cycle and these equations are important for future projections of sunn hemp growth. These results were also observed for the other traits. In the Gompertz model, the IP was attained when the plant reached approximately $50 \%$ of its growth, considering the $\mathrm{PH}, \mathrm{NL}$, and SD traits. However, the IP was reached at 19 DAS for the RL traits, which confirms that this type of model is not adequate for describing this traits, because the behavior did not fit the traits of the model. In the Logistic model, the IP was also reached after the plant reached $50 \%$ of its growth with regard to $\mathrm{PH}, \mathrm{NL}$, and $\mathrm{SD}$; however, for RL this value was reached at 27 DAS. This indicates that if the crop requires any treatment, such as pest and disease control, fertilization, irrigation, and weed control, it should be performed before the growth curve reaches the IP. At this point, increasing growth rates begin to decrease, after the IP the growth of sunn hemp tends to stabilize at the end of its cycle, with the growth rate of the plant decreasing until full flowering and the plant not responding to crop treatments.

Moreover, the models that represented the $\mathrm{PH}$, NL, and SD traits exhibited a sigmoidal shape, which is expected when they are fitted to growth models. This shape has been well identified in studies involving banana tree growth curves (MAIA et al., 2009) and the accumulation of dry matter of onion bulbs (PÔRTO et al., 2007). However, the behavior of the RL traits was different from the other assessed traits. An adequate model for fitting these traits would be the Brody model, which is recommended for fitting curves to data that do not exhibit sigmoidal behavior; however, this model does not exhibit an IP, which hinders the practical interpretation of the fitted curve. 
Figure 1. Adjusted to fit Gompertz and Logistic, and IP (inflection point) for the morphological traits plant height (PH), number of leaves (NL), stem diameter SD (mm), and root length (RL) in first sowing period (October 22, 2014).
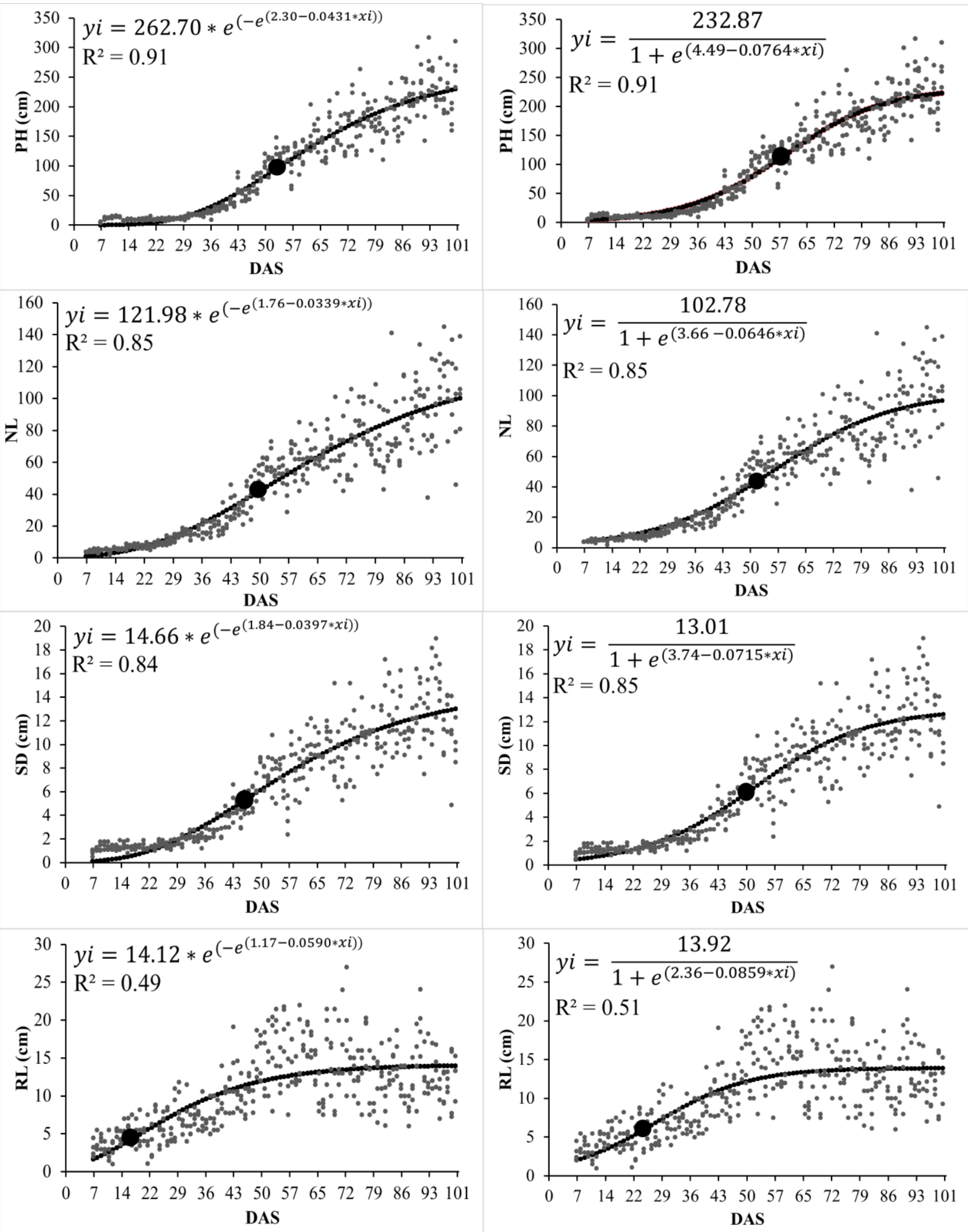

"First sowing periods $=$ October 22, 2014 and evaluation = October 29, $2014(x i=7) .{ }^{* *}$ Left column Gompertz model and rigth column Logistic model. • Inflection points (xi;yi). 
Figure 2 illustrates the growth curves, their respective equations, and IPs of the Gompertz and Logistic models during second period with regard to the $\mathrm{PH}, \mathrm{NL}, \mathrm{SD}$, and RL traits. The equation of the Gompertz model fitted to $\mathrm{PH}$ in second period was $y i=304.10 * e^{\left(-e^{(2.06-0.0391 * x i))}\right.}$ and the equation of the Logistic model was $y i=\frac{257.65}{1+e^{(4.26-0.0746 * x i)}}$ using DAS as the independent variable $(x i)$, and what was inferred for period 1 also applies to second period. In the Gompertz model, the IP was reached a few days before the plant reached half of its growth cycle when compared to the Logistic model. This result was expected because the formula for the calculation of $y i$ differs between the two models. These graphs represent the fitting of the models under study and sigmoidal behavior is best represented by the Logistic model for the PH, NL, and SD traits. However, the curves do not exhibit a sigmoidal behavior in the case of RL.

Figure 2. Adjusted to fit Gompertz and Logistic, and IP (inflection point) for the morphological traits plant height $(\mathrm{PH})$, number of leaves (NL), stem diameter SD (mm), and root length (RL) in second sowing period (December 3, 2014).
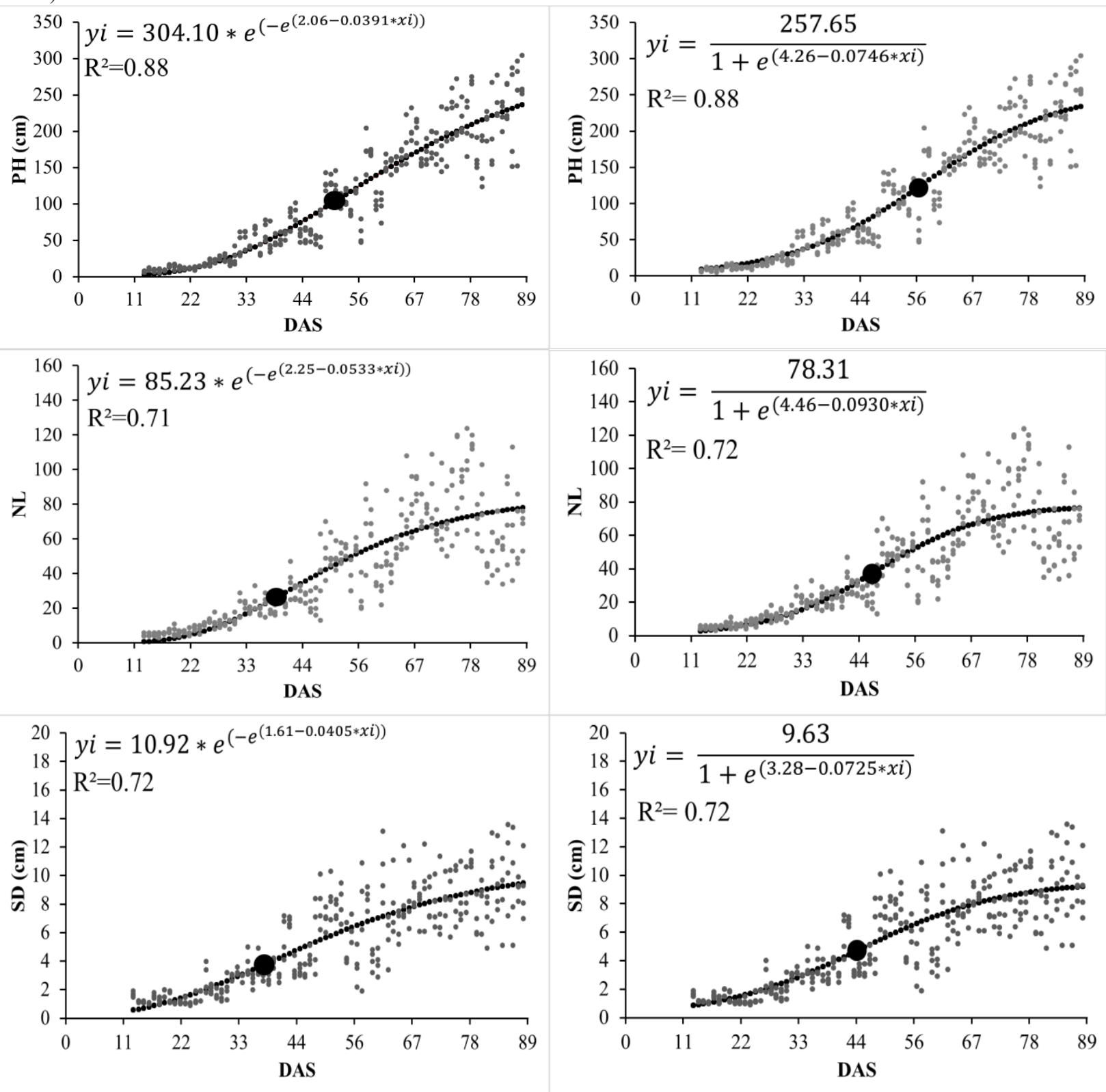

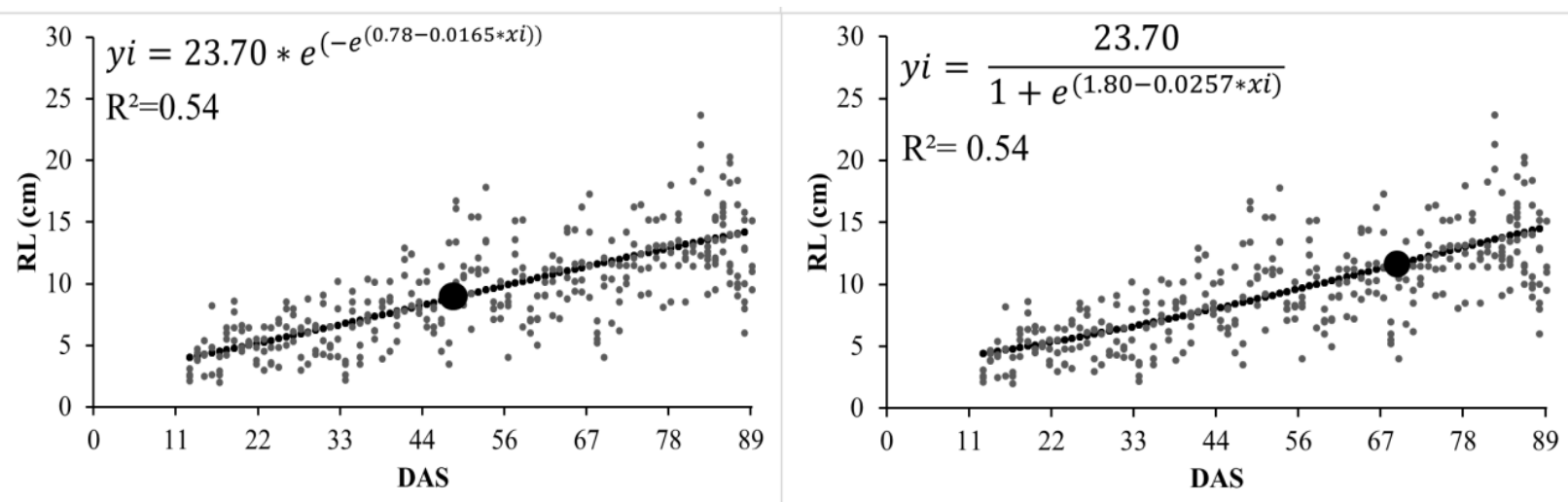

${ }^{*}$ Second sowing periods $=$ December 3, 2014 and evaluation $=$ December 16, $2014(x i=13) .{ }^{* *}$ Left column Gompertz model and rigth column Logistic model. • Inflection points $(x i ; y i)$.

The results of the present study could be useful as reference material for future research on sunn hemp crops, because it has been demonstrated that the Gompertz and Logistic models are adequate when fitted to the data of morphological traits.

\section{Conclusion}

The Gompertz and Logistic growth models adjusted for the traits plant height, leaf number, stem diameter and root length differ from one another, and differ between sowing periods and estimates for model parameter.

The growth curves for plant height, leaf number and stem diameter presented satisfactory adjustments for both the Gompertz model and the Logistic model, through the evaluation criteria of the fit quality of the models, with no difference between, and not differing between sowing times. However, the evaluator of the quality of fit mean prediction error, obtained different results when compared the models and the sowing periods.

For the root length trait, the Gompertz and Logistic models did not fit the data, and a new model must be studied.

\section{Acknowledgments}

To the National Council of Scientific and Technological Development (CNPQ), the Coordination of Improvement of Personnel of Superior Level (CAPES) and the Foundation of Amparo the Research of the state of Rio Grande do Sul (FAPERGS), by the granting of scholarship to the authors. Student fellows and volunteers assisted in data collection.

\section{References}

DEPRÁ, M. S.; LOPES, S. J.; NOAL, G.; REINIGER, L. R. S.; COCCO, D. T. Modelo logístico de crescimento de cultivares crioulas de milho e de progênies de meiosirmãos maternos em função da soma térmica. Ciência Rural, Santa Maria, v. 46, n. 1, p. 36-43, 2016.

DINARDO-MIRANDA, L. L.; GIL, M. A. Efeito de rotação com Crotalaria juncea na produtividade de canade-açúcar tratada ou não com nematicidas no plantio. Revista de Nematologia Brasileira, Piracicaba, v. 29, n. 1, p. 63-66, 2005.

DIONELLO, R. G.; BERBET, P. A.; MOLINA, M. A. B.; PEREIRA, R. C.; VIANA, A. P.; CARLESSO, V. de. O. Secagem de fatias de abacaxi in natura e pré-desidratadas por imersão-impregnação: cinética e avaliação de modelos. Ciência e Tecnologias de Alimentos, Campinas, v. 29, n. 1, p. 232-240, 2009.

DOURADO, M. C.; SILVA, T. R. B.; BOLONHEZI, A. C. Matéria seca e produção de grãos de Crotalaria juncea L. submetida à poda e adubação fosfatada. Scientia Agrícola, Piracicaba, v. 58, n. 2, p. 287-293, 2001. 
DRAPER, N. R.; SMITH, H. Applied regression analysis. $2^{\text {th }}$ ed. New York: John Wiley \& SonsInc., 1981.709 p. Applied regression analysis. $3^{\text {th }}$ ed. New York: J. Wiley, $1998.706 \mathrm{p}$.

FERNANDES, T. J.; PEREIRA, A. A.; MUNIZ, J. A.; SAVIAN, T. V. Seleção de modelos não lineares para a descrição de curvas de crescimento do fruto do cafeeiro. Coffee Science, Lavras, v. 9, n. 2, p. 207-215, 2014.

GONZAGA, T. W. C.; MATA, M. E. R. M. C.; SILVA, H.; DUARTE, M. E. M. Crioconservação de sementes de aroeira (Astronium urundeuva Engl.), e baraúna (Schinopsis brasiliensis Engl.). Revista Brasileira de Produtos Agroindustriais, Campina Grande, v. 5, n. 2, p. 145-154, 2003.

HAEFNER, J. W. Modeling biological systems: principles and applications. New York: Springer, 2005. 475 p.

LEAL, M. A. A.; GUERRA, J. G. M.; PEIXOTO, R. T. G.; ALMEIDA, D. L. de. Desempenho de crotalária cultivada em diferentes épocas de semeadura e de corte. Revista Ceres, Viçosa, MG, v. 59, n. 3, p. 386-391, 2012.

LÚCIO, A. D.; NUNES, L. F.; REGO, F. Nonlinear models to describe production of fruit in Cucurbita pepo and Capiscum annuum. Scientia Horticulturae, Amsterdam, v. 193, n. 13, p. 286-293, 2015.

LYRA, G. B.; LYRA, G. B.; ROCHA, A. E. Q.; TEODORO, I.; PONCIANO, N. J.; SANTOS, M. A. Produtividade e modelos de crescimento para o mamoeiro cultivar Golden. Revista Ciência Agrícola, Rio Largo, v. 11, n. 1, p. 1-12, 2013.

LYRA, G. B.; ZOLNIER, S.; COSTA, L. C.; SEDIYAMA, G. C.; SEDIYAMA, M. A. N. Modelos de crescimento para alface (Lactuta sativa L.) em sistema hidropônico sob condições de casa-de-vegetação. Revista Brasielira de Agrometeorologia, Santa Maria, v. 11, n. 1, p. 69-77, 2003.

MAIA, E.; SIQUEIRA, D. L.; SILVA, F. F.; PETERNELLI, L. A.; SALOMÃO, L. C. C. Método de comparação de modelos de regressão não-lineares em bananeiras. Ciência Rural, Santa Maria, v. 39, n. 5, p. 1380-1386, 2009.

MARTINS FILHO, S.; SILVA, F. F.; CARNEIRO, A. P. S.; MUNIZ, J. A. Abordagem bayesiana das curvas de crescimento de duas cultivares de feijoeiro. Ciência Rural, Santa Maria, v. 38, n. 6, p. 1516-1521, 2008.
PEREIRA, J.; MUNIZ, J. A.; SILVA, C. A. Non linear models to predict nitrogen mineralization in na oxisol. Scientia Agrícola, Santa Maria, v. 62, n. 4, p. 395-400, 2005.

PÔRTO, D. R. Q.; CECÍlIO FILHO, A. B.; MAY, A.; VARGAS, P. F. Acúmulo de macronutrientes pela cultivar de cebola Superex estabelecida por semeadura direta. Ciência Rural, Santa Maria, v. 37, n. 4, p. 949955, 2007.

R DEVELOPMENT CORE TEAM - R: a language and environment for statistical computimg. Vienna: $\mathrm{R}$ Foundation for Statistical Computing, 2017.

REIS, R. M.; CECON, P. R.; PUIATTI, M.; FINGER, F. L.; NASCIMENTO, M.; SILVA, F. F.; CARNEIRO, A. P. S.; SILVA, A. R. Modelos de regressão não linear aplicados a grupos de acesso de alho. Horticultura Brasileira, Brasília, v. 32, n. 2, p. 178-183, 2014.

SILVEIRA, F. G.; SILVA, F. F.; CARNEIRO, P. L. S.; MALHADO, C. H. M. Classificação multivariada de modelos de crescimento para grupos genéticos de ovinos de corte. Revista Brasileira de Saúde e Produção Animal, Salvador, v. 13, n. 1, p. 62-73, 2012.

SORATO, A. M. C.; PRADO, T. K. L.; MORAIS, A. R. Análise do crescimento vegetal por meio de modelo não linear via regressão isotônica. Revista da Estatística, Ouro Preto, v. 3, n. 3, p. 139-143, 2014.

SOUSA, I. F.; KUNZLE NETO, J. E.; MUNIZ, J. A.; GUIMARÃES, R. M.; SAVIAN, T. V.; MUNIZ, F. R. Fitting nonlinear autoresgressive models to describe coffe seed germination. Ciência Rural, Santa Maria, v. 44, n. 11, p. 2016-2021, 2014.

STRECK, N. A.; BOSCO, L C.; LUCAS, D. D. P.; LAGO, I. Modelagem da emissão de folhas em arroz. Pesquisa Agropecuária Brasileira, Brasília, v. 43, n. 5, p. 559-567, 2008.

TERRA, M. F.; MUNIZ, J. A.; SAVIAN, T. V. Ajuste dos modelos Logístico e Gompertz aos dados de crescimento de frutos de tamareira anã (Phoenix roebelenni O'BRIEN). Magistra, Cruz das Almas, v. 22, n. 1, p. 1-7, 2010 . 
